\title{
Contribuições de Maria Aparecida Baccega aos Estudos de Recepção ${ }^{1}$
}

\section{Maria Aparecida Baccega's contributions for Reception Studies}

Roseli Figaro ${ }^{2}$

Resumo: Este artigo tem o objetivo de registrar e discutir as contribuições de Maria Aparecida Baccega (1943-2020) aos estudos de recepção. Trata-se de estudo bibliográfico em que se busca cotejar os principais conceitos trabalhados por Baccega com base em levantamento realizado sobre sua obra em revistas acadêmicas, livros e capítulos de livros, anais de eventos científicos, bem como do registro das teses e dissertações que a pesquisadora orientou ao longo de sua vida acadêmica. Não pretende ser um levantamento exaustivo e muito menos conclusivo. Propõe-se destacar a compreensão dela sobre os conceitos de sujeito social, produção de sentido, mediações, recepção e consumo. Este estudo se justifica porque se vincula a uma tradição de estudos sobre teóricos latino-americanos e suas contribuições relevantes para a área da comunicação.

Palavras-chave: Maria Aparecida Baccega; estudos de recepção; discurso.

Abstract: This article aims to record and discuss the contributions of Maria Aparecida Baccega (1943-2020) to reception studies. This is a bibliographic study based on the author's work in academic journals, books and book chapters, annals of scientific events as well as the registration of the theses and dissertations that she has guided throughout her academic life. It is not intended to be an exhaustive research, much less conclusive. Based on our view of the author's work, it is proposed to record her understanding of the concepts of social subject,

1 Artigo aprovado para ser apresentado ao GT Recepção, Circulação e usos sociais das mídias, do $29^{\circ}$ Encontro da Compós, UFMS, 2020.

2 Universidade de São Paulo (USP). São Paulo, SP, Brasil.

https://orcid.org/0000-0002-9710-904X. E-mail: figaro@uol.com.br 
400 CONTRIBUIÇÕES DE MARIA APARECIDA BACCEGA

production of meaning, mediations, reception and consumption. This study is justified because it is linked to a tradition of studies on Latin American theorists and their relevant contributions to the area of communication.

Keywords: Maria Aparecida Baccega; reception studies; speeach. 


\section{Introdução}

É objetivo deste artigo tratar especificamente da trajetória ${ }^{3}$ de produção intelectual de Maria Aparecida Baccega (1943-2020) sobre o tema dos estudos de recepção. A autora, professora doutora e livre-docente atuou durante 25 anos na Escola de Comunicações e Artes da USP e, depois de aposentada, na Escola Superior de Propaganda e Marketing de São Paulo, à frente do Programa de Pós-graduação em Comunicação e Práticas de Consumo. No percurso acadêmico, Baccega destacou-se nos estudos do discurso, como especialista em linguagem verbal, editora de periódicos científicos; pesquisadora da linguagem e de análise do discurso, dos estudos de telenovela, da gestão dos processos comunicacionais e das inter-relações de comunicação e educação. Em levantamento que realizamos sobre sua obra, na base do currículo Lattes, encontramos 77 artigos científicos publicados em periódicos nacionais e estrangeiros, 61 capítulos de livros e 29 livros. Ela também orientou 18 mestrados e 14 doutorados. Apresentou trabalhos em inúmeros congressos, seminários e eventos cujos anais registram sua participação e contribuição. Dessa obra extensa, a reflexão que aqui desenvolvemos preocupa-se centralmente com as contribuições de Baccega aos estudos de recepção no que diz respeito aos conceitos de sujeito social, receptor, mediações, consumo. Todos esses conceitos foram discutidos por ela tendo em conta teorias da linguagem verbal, principalmente sob a perspectiva da circulação dos discursos e da produção de sentidos.

Dividimos nossa análise em três eixos: aspectos metodológicos da pesquisa e contextualização da obra de Baccega, dando destaque para a

3 Vale destacar as trajetórias já documentadas de Eliseo Veron, Mario Kaplun, José Marques de Melo, Luiz Beltrão, Jesús Martin-Barbero, Armand Mattelart, Memórias da Comunicação Grupo Gaúcho, do Grupo Uspiano e tantos mais, em projetos sobre a memória da pesquisa em Comunicação no país. Algumas publicações: Melo, José Marques de; Dias, Paulo Rocha (Orgs.) Comunicação, cultura, mediações. O percurso intelectual de Jesús Martín-Barbero. São Bernardo do Campo: Universidade Metodista, 2000. Melo, José Marques de; Santos, Marli. (Orgs.). Mutações na Comunicação: ampliando as fronteiras do jornalismo. Luiz Beltrão. São Paulo: Umesp/Intercom, 2016. Melo, José Marques de (Org.) Fortuna crítica de Luiz Beltrão. Dicionário bibliográfico. São Paulo: Intercom/Umesp, 2012. Maldonado, Alberto Efendy; Castro, Edizon León (Org.). Investigación crítica de la comunicación en América Latina: diálogos con la vertiente Mattelart. Quito: Ciespal, 2019. 
sua produção relativa aos estudos de recepção; a concepção dela sobre o papel da linguagem e da comunicação na conformação do sujeito social; decorrente dessa compreensão, a análise/discussão que faz acerca dos conceitos de mediação, recepção e consumo. Por fim, faremos alguns apontamentos sobre as contribuições da autora, tendo em vista os estudos de recepção para a inter-relação comunicação e educação e ficção televisiva.

\section{Trajetória de contribuições ao campo da comunicação: um recorte com método}

O método para esta pesquisa, cujo objetivo é identificar e analisar a contribuição de uma trajetória acadêmica sobre os estudos de recepção, foi o levantamento bibliográfico e a análise contextualizada dos conceitos destacados com base em palavras-chave, títulos e resumos. Também a leitura atenta do material selecionado proporcionou identificar um cenário teórico pelo qual a autora transitou durante sua produção acadêmica. Assis ([s.d.] on-line) faz um levantamento bibliométrico da obra de Baccega registrada até 2012, por meio dos dados recuperados do currículo Lattes atualizado até então. Naquele estudo, Assis identifica o perfil central da intelectual Maria Aparecida Baccega cuja característica é a prática interdisciplinar na produção científica, no interesse de pesquisa e na abordagem teórica que dá aos conceitos que desenvolve nas análises dos objetos empíricos.

O diferencial que aqui se apresenta é centrarmos nosso objetivo na análise das contribuições de Baccega para os estudos de recepção por meio do método do estudo bibliográfico, focado na obra da autora. Para isso, seguimos os passos indicados por Treinta et al. (2012) para a definição do tema: estudos de recepção; palavras-chave de busca: sujeito social, receptor, consumo, mediações; bem como a pergunta mestra da investigação: qual a contribuição de Maria Aparecida Baccega para os estudos de recepção? Definido o objetivo, a pergunta de pesquisa, os conceitos-chave que orientam o objetivo da pesquisa, partimos para a 
busca desses termos-chave na obra de Baccega, tendo como universo os dados disponíveis no currículo Lattes e declarados pela autora. A partir do conjunto da obra, foram selecionados para compor a amostra artigos, capítulos de livros, livros e artigos dos Encontros Nacionais da Compós, que indicassem em seu corpo textual de título, palavra-chave e/ou resumo, algum dos conceitos escolhidos (recepção, sujeito social, consumo, mediações). Mapeamos todos os dados e compusemos uma planilha no Excel para termos a dimensão das informações a serem analisadas. Feita a leitura dos títulos, palavra-chave e resumos, partimos para a seleção do corpus a ser analisado. O conjunto de textos selecionados foram 20 artigos em periódicos científicos; 15 capítulos de livros, 6 livros e 2 artigos apresentados nos Encontros Anuais da Compós, bem como um artigo apresentado com template da Compós, mas não encontrado nos anais dos encontros nem entre os artigos da revista E-Compós, o endereço da base do artigo é http://www.compos.org.br/data/biblioteca_1283.pdf. As teses e dissertações que Baccega orientou também fizeram parte de nosso universo de pesquisa. Passamos a relacionar o material selecionado para a análise, conforme o objetivo deste artigo.

Quadro 1 - Artigos publicados em periódicos

BUDAG, FERNANDA ELOUISE; MARCELINO, ROSILENE MORAES ALVES; ABRÃO, MARIA AMÉLIA PAIVA; BACCEGA, MARIA APARECIDA. Consumo e Cidadania: em perspectiva a recepção do rap da periferia paulistana. Comunicação ๒ Educação (USP), v. 20, p. 47-55, 2015.

BACCEGA, M. A.; BUDAG, F. E.; RIBEIRO, L. M. Rebelde(s): consumo e valores nas telenovelas brasileira e mexicana. Comunicação \& Educação (USP), v. 18, p. 95-104, 2013.

BACCEGA, M. A.; ANTONACCI, A. A transmidialidade em morde\&assopra: uma reflexão sobre consumo cultural e construções narrativas. Comunicação \& Educação (USP), v. 18, p. 89-98, 2013.

BACCEGA, M. A.; CASTRO, G. S. ; RIZZO, M. Retos en la investigación sobre consumo cultural y comunicación. Portal Comunicación.com, v. 1, p. 00-00, 2012.

MARCELINO, R. M. A.; BACCEGA, M. A. Clô: uma personagem da sociedade de consumo. Comunicação Đ Educação (USP), v. 1, p. 99-112, 2011. 


\section{Quadro l - Continuação}

BACCEGA, M. A. Comunicação/educação: relações com o consumo. Importância para a constituição da cidadania. Comunicação, Mídia e Consumo, v. 7, p. 49-66, 2010.

BACCEGA, M. A. Construindo a cidadania nas interrelações comunicação, educação e consumo. Conexiones. Revista Iberoamericana de Comunicación, v. 2, p. 20-29, 2010.

BACCEGA, M. A.; MACEDO, Diana Gualberto de. Afinal, o que é gênero em comunicação? O consumo da programação midiática televisiva. Comunicação \& Informação (UFG), v. 13, p. 01-11, 2010.

BACCEGA, M. A.; CASTRO, G. S. . Comunicação e consumo: cidadania em perigo? Revista da ESPM, v. 16, p. 56-60, 2009.

BACCEGA, M. A.. Comunicação/Educação e a construção de nova variável histórica. Comunicação ๒ Educação, v. 3, p. 1-10, 2009.

BACCEGA, M. A.. Inter-relações comunicação e consumo na trama cultural: o papel do sujeito ativo. Animus (Santa Maria Online), v. 15, p. 1-15, 2009.

BACCEGA, M. A. Discurso da comunicação: encontro de ficção e realidade. Comunicação ๒ Educação (USP), v. 12, p. 23-34, 2007.

BACCEGA, M. A.; GUIMARÃES, M. O. Da comunicação à educação: a importância dos estudos de recepção. Comunicação ๒ Educação (USP), v. 11, n. 3, p. 409-414, 2006.

BACCEGA, M. A. Comunicação: interação emissão/recepção. Comunicação ๒ Educação (USP), São Paulo: Editora Salesiana, v. VIII, n. 23, p. 7-15, 2002.

BACCEGA, M. A. Meios de Comunicação na Escola. Comunicação ๒ Educação (USP), São Paulo, v. IX, n. 25, p. 7-15, 2002.

BACCEGA, M. A. Comunicação/Educação: conhecimento e mediações. Comunicação ๒ Educação (USP), São Paulo, v. VII, n. 20, p. 7-14, 2001.

BACCEGA, M. A. A Construção do Campo Comunicação/Educação: alguns caminhos. Comunicação ๒ Educação (USP), São Paulo, v. VII, n. 48, p. 18-31, 2001.

BACCEGA, M. A. Recepção: nova perspectiva nos estudos de Comunicação. Comunicação ๒ Educação, São Paulo, v. VI, n. 12, p. 7-16, 1998.

BACCEGA, M. A. Comunicação e Mediações. Comunicação ๒ Educação (USP), São Paulo: Editora Moderna, v. 1, n. 4, p. 7-12, 1995.

Baccega, M. A. Do mundo editado à construção do mundo. Comunicação ๒ Educação, (1), 7-14, 1994.

Fonte: Autor 


\section{Quadro 2 Capítulos de livros}

TONDATO, M. P.; BACCEGA, M. A.; ANTONACCI, A.; ROCHA, C. R. N. C.; ABRÃO, MARIA AMÉLIA PAIVA; JUNQUEIRA, A. H.; SABOIA, C. T. N.; BUDAG, F. E. Novos formatos teleficcionais e a recepção da televisão de qualidade no Brasil: um olhar para a supersérie onde nascem os fortes. A construção de mundos na ficção televisiva brasileira. 1. ed. Porto Alegre: Sulina, 2019, v. 6, p. 225-247.

BACCEGA, MARIA APARECIDA; ROCHA, C. R. N. C. A importância da inter-relação entre o campo da comunicação /educação e os estudos de recepção: um olhar para a comunicação a partir dos sujeitos. In: KUNSCH, Margarida; FIGARO, Roseli (Org.). Comunicação e educação: caminhos integrados para um mundo em transformação. 1. ed. São Paulo: Intercom, 2017, v. 1, p. 71-88.

BACCEGA, M. A. Comunicação, educação e consumo: encontros. In: ROCHA, Rose de Melo; PERES-NETO, Luiz (Org.). Memória, comunicação e consumo: vestígios e prospecções. 1. ed. Porto Alegre: Sulina, 2015, v. 1, p. 21-32.

BACCEGA, M. A. Dicionário de comunicação: escolas, teorias e autores (verbete Comunicação e Consumo), p. 53-65. 1. ed. São Paulo: Editora Contexto, 2014. v. 1. 8p.

BACCEGA, M. A. Comunicação/educação a construção de nova variável histórica. In: CITELLI, Adilson Odair; COSTA, Maria Cristina Castilho (Org.). Educomunicação: construindo uma nova área de conhecimento. 1. ed. São Paulo: Paulinas, 2011, v. 1, p. 31-42.

BACCEGA, M. A. Reflexões sobre as relações comunicação/educação e consumo. In: José Marques de Melo. (Org.). Pensamento comunicacional Uspiano: impasses mundializadores na escola de Comunicações e Artes. São Paulo: SOCICOM, 201 l, v. 2, p. 203-213.

BACCEGA, M. A. Inter-relações comunicação e consumo na trama cultural: o papel do sujeito ativo. In: CARASCOZA, João Anzanello ; ROCHA, Rosamaria de Melo. (Org.). Consumo midiático e culturas da convergência. São Paulo: Miró Editorial, 2011, v. , p. 26-44.

BACCEGA, M. A. Reflexões sobre as relações comunicação/educação e consumo. In: BARBOSA, Marialva ; MORAIS, Osvando J. de (Org.). Comunicação, Cultura e Juventude. São Paulo: INTERCOM, 2010, v. 1, p. 433-446.

BACCEGA, M. A.; BUDAG, F. Representações em Rebelde e recepção de Rebelde: o global e o local na comunicação e no consumo. In: Centro de Altos Estudos da ESPM-(CAEPM) (Org.). Arenas da comunicação com o mercado: articulações entre consumo, entretenimento e cultura. led. São Paulo: Alameda Casa Editorial, 2010, v.1, p. 233-248.

BACCEGA, M. A. Campo comunicação/Educação: mediador do processo de recepção. In: BACCEGA, M. A.; COSTA, Maria Cristina Castilho (Org.). Gestão da comunicação: epistemologia e pesquisa teórica. São Paulo: Paulinas, 2009, v. , p. $13-$ 
Quadro 2 - Continuação

BACCEGA, M. A. Inter-relações comunicação e consumo na trama cultural: o papel do sujeito ativo. In: CASTRO, Gisela; TONDATO, M. (Org.). Caleidoscópio midiático: o consumo pelo prisma da comunicação. São Paulo: ESPM, 2009, v.1 , p. 4-20.

BACCEGA, M. A. Campo comunicação educação: mediador do processo de recepção. In: CASTRO, Gisela Grangeiro da Silva; TONDATO, Márcia (Org.). Caleidoscópio midiático: o consumo pelo prisma da comunicação. São Paulo: ESPM-SP, 2009, v.1 , p. 22-42.

BACCEGA, M. A. Comunicação educação e consumo: relações. In: CASTRO, Gisela Grangeiro da Silva; BACCEGA, Maria Aparecida (Org.). Comunicação e consumo nas culturas locais e global. São Paulo: ESPM, 2009, v.1 , p. 1-11.

BACCEGA, M. A.; TONDATO, M.; MACEDO, D.; SANTANA, F. C. Gêneros televisivos e publicidade no prime-time português e brasileiro: a recepção como suporte das relações entre comunicação e práticas de consumo. In: MARTINS, Moisés de Lemos; CABECINHAS, Rosa (Org.). Anuário internacional de comunicação lusófona 2009: memória social e dinâmicas identitárias. Portugal: Grácio Edutor, 2009, v.1, p. 1-270.

BACCEGA, M. A. O impacto da publicidade no campo da comunicação/educação: recepção de professores e alunos do Ensino Médio. In: SOUSA, Helena; MARINHO, Sandra (Org.). Anuário Internacional de Comunicação Lusófona 2007: os media no espaço lusófono. Minho PT: Campo das Letras, 2007, v.1 , p. 327-344.

Fonte: Autor

\section{Quadro 3 Livros}

TONDATO, Márcia; BACCEGA, M. A. Telenovela nas relações comunicação e consumo: diálogos Brasil e Portugal. 1. ed. São Paulo: Paco Editorial, 2013. v. 1. 206p.

BACCEGA, M. A.; OROFINO, M. I. (Org.). Consumindo e vivendo a vida: telenovela e consumo e seus discursos. 1. ed. São Paulo: Intermeios, 2012. v. 1. 202p.

BACCEGA, M. A. Comunicación y culturas del consumo. 1. ed. Espanha: Comunicación Sociales, Saracozza, 2012.

CASTRO, G. S. ; BACCEGA, M. A. (Org.). Comunicação e consumo nas culturas locais e global. São Paulo: ESPM, 2009. 615p.

BACCEGA, M. A. Palavra e discurso: história e literatura. São Paulo: Ática, 1995. 96p.

BACCEGA, M. A. Comunicação e Linguagem: discursos e ciência. São Paulo: Editora Moderna, 1998. v. 1. 127p.

Fonte: Autor 


\section{Quadro 4 Encontros da Compós}

BACCEGA, M. A. Inter-relações comunicação e consumo: receptor e consumidor. In: $18^{\circ}$ Compós, 2009, Belo Horizonte. XVIII Encontro Anual da Compós: Associação Nacional de Programas de Pós-Graduação em Comunicação. São Paulo: Compós, 2009. p. 1-13.

JUNQUEIRA, A. H.; BACCEGA, M. A. O processo de construção da imagem do receptor pelo enunciador na comunicação persuasiva: um estudo de caso na publicidade institucional de flores e plantas ornamentais no Brasil. In: $17^{\circ}$ Encontro Anual da Associação Nacional dos Programas de Pós-Graduação em Comunicação. São Paulo: Compós/Unip, 2008. p. 1-17.

BACCEGA, M. A. O campo da comunicação/educação e as práticas de recepção: o papel das mediações. http://www.compos.org.br/data/biblioteca_1283.pdf.

Este terceiro artigo com template da Compós não foi encontrado nem nos anais dos congressos nem entre os artigos da E-Compós. No entanto, por acaso, o encontramos via Google.

Fonte: Autor

A leitura do material selecionado permite afirmar que a preocupação da autora é definir a comunicação tendo como escopo os estudos da linguagem, considerados a partir da problemática das relações entre discursos, sempre situados, perpassados por condições de produção e, portanto, pelas injunções sociais, culturais e ideológicas que os enformam. Esse esteio permite reivindicar o campo da comunicação como produção/recepção simultaneamente. Assim, Baccega nega a linearidade e a transmissão como termos explicativos da comunicação. Traz para a arena conceitual a problematização da comunicação como campo de inter-relações no qual se retroalimentam simultaneamente as posições de produção/recepção. Com essa formulação, Baccega contesta a linhagem das teorias da comunicação lastreadas no Funcionalismo e no Estruturalismo, correntes clássicas que orientaram grande parte das pesquisas na área da Comunicação no século XX.

É interessante verificar como essa trajetória intelectual de Baccega deu lastro às teses e dissertações de jovens pesquisadores por ela orientados. Das 32 orientações, entre 14 doutorados e 18 mestrados, temos 18 trabalhos relativos à temática da recepção e/ou consumo, conforme demonstra o Quadro 5. 
Quadro 5 - Teses e dissertações com o tema da recepção e/ou consumo

\begin{tabular}{|c|c|c|c|c|}
\hline Nível & Título & Autor & Ano & Instituição \\
\hline DO & $\begin{array}{l}\text { Estudo de recepção: o mundo } \\
\text { do trabalho como mediação da } \\
\text { comunicação }\end{array}$ & FIGARO, Roseli & 1999 & ECA-USP \\
\hline $\mathrm{DO}$ & $\begin{array}{l}\text { Negociação de sentido: recepção } \\
\text { da programação de tv aberta. }\end{array}$ & $\begin{array}{l}\text { TONDATO, } \\
\text { Marcia P. } \\
\end{array}$ & 2004 & ECA-USP \\
\hline $\mathrm{DO}$ & $\begin{array}{l}\text { O cotidiano e a cultura: mediações } \\
\text { em que se tece o sentido }\end{array}$ & $\begin{array}{l}\text { GUIMARÃES, } \\
\text { Margaret O. } \\
\end{array}$ & 2006 & ECA-USP \\
\hline $\mathrm{ME}$ & $\begin{array}{l}\text { Recepção: heterogeneidades e } \\
\text { negociações de sentidos. O jorna- } \\
\text { lismo político e os sujeitos leitores } \\
\text { das revistas semanais }\end{array}$ & $\begin{array}{l}\text { AZEVEDO, Ali- } \\
\text { ne Fernandes de }\end{array}$ & 2006 & ECA-USP \\
\hline $\mathrm{ME}$ & $\begin{array}{l}\text { Comunicação em rede, novos } \\
\text { agentes socializadores e recepção } \\
\text { práticas culturais: o consumo de } \\
\text { Internet em lan houses na periferia } \\
\text { de São Paulo } \\
\end{array}$ & $\begin{array}{l}\text { BREDARIOLI, } \\
\text { Claudia Maria } \\
\text { Moraes }\end{array}$ & 2008 & ESPM \\
\hline $\mathrm{ME}$ & $\begin{array}{l}\text { Comunicação, recepção e consu- } \\
\text { mo entre o Guarani: o índio na } \\
\text { mídia e a mídia na vida do índio }\end{array}$ & $\begin{array}{l}\text { VENDRAME, } \\
\text { Sonia I. }\end{array}$ & 2009 & ESPM \\
\hline ME & $\begin{array}{l}\text { Comunicação, recepção e con- } \\
\text { sumo construção de sentidos na } \\
\text { arena do popular: a berlinda do } \\
\text { Círio de Nazaré como suporte } \\
\text { midiático } \\
\end{array}$ & $\begin{array}{l}\text { JUNQUEIRA, } \\
\text { Antonio Hélio }\end{array}$ & 2009 & ESPM \\
\hline $\mathrm{ME}$ & $\begin{array}{l}\text { Comunicação, recepção e con- } \\
\text { sumo: inter-relações. O receptor/ } \\
\text { consumidor no prime time brasi- } \\
\text { leiro e português }\end{array}$ & $\begin{array}{l}\text { MACEDO, Dia- } \\
\text { na Gualberto de }\end{array}$ & 2010 & ESPM \\
\hline $\mathrm{ME}$ & $\begin{array}{l}\text { Comunicação, recepção e con- } \\
\text { sumo: as manifestações culturais } \\
\text { e sua influência na formação das } \\
\text { identidades. Um estudo sobre as } \\
\text { telenovelas Duas Caras (brasileira) } \\
\text { e A Outra (portuguesa) }\end{array}$ & $\begin{array}{l}\text { ABRÃO, Maria } \\
\text { Amélia Paiva }\end{array}$ & 2010 & ESPM \\
\hline $\mathrm{ME}$ & $\begin{array}{l}\text { Comunicação, educação e con- } \\
\text { sumo: a circulação de práticas de } \\
\text { consumo na intraficção e a sua } \\
\text { apropriação por estudantes }\end{array}$ & $\begin{array}{l}\text { MARCELINO, } \\
\text { Rosilene M. } \\
\text { Alves }\end{array}$ & 2012 & ESPM \\
\hline
\end{tabular}


Quadro 5 - Continuação

\begin{tabular}{|c|c|c|c|c|}
\hline $\mathrm{ME}$ & $\begin{array}{l}\text { Comunicação, consumo e educa- } \\
\text { ção: o caso da telenovela Amor e } \\
\text { Revolução }\end{array}$ & $\begin{array}{l}\text { ARAUJO, Dayse } \\
\text { Maciel de }\end{array}$ & 2013 & ESPM \\
\hline $\mathrm{ME}$ & $\begin{array}{l}\text { Comunicação, consumo e edu- } \\
\text { cação: os discursos sobre ciência } \\
\text { na telenovela Morde \& Assopra: } \\
\text { uma aventura interdisciplinar } \\
\text { sobre aprender, apreender, ouvir e } \\
\text { contar histórias }\end{array}$ & $\begin{array}{l}\text { ANTONACCI, } \\
\text { Andrea Celeste } \\
\text { Montini }\end{array}$ & 2013 & ESPM \\
\hline ME & $\begin{array}{l}\text { Comunicação, recepção e } \\
\text { consumo: suas inter-relações em } \\
\text { rebelde-RBD }\end{array}$ & $\begin{array}{l}\text { BUDAG, Fer- } \\
\text { nanda E. }\end{array}$ & 2014 & ESPM \\
\hline $\mathrm{ME}$ & $\begin{array}{l}\text { Retratos do brasileiro no imagi- } \\
\text { nário equatoriano: um estudo de } \\
\text { recepção da telenovela Avenida } \\
\text { Brasil em Guayaquil }\end{array}$ & $\begin{array}{l}\text { NOVAES, Liz- } \\
\text { beth C. Kanyat } \\
\text { Ojeda de }\end{array}$ & 2014 & ESPM \\
\hline $\mathrm{ME}$ & $\begin{array}{l}\text { Comunicação, educação e } \\
\text { consumo: por uma pedagogia da } \\
\text { igualdade e da liberdade }\end{array}$ & $\begin{array}{l}\text { PIRES, Regina } \\
\text { de Lima }\end{array}$ & 2016 & ESPM \\
\hline $\mathrm{ME}$ & $\begin{array}{l}\text { O conceito de família na telenove- } \\
\text { la: um estudo sobre sua recepção }\end{array}$ & $\begin{array}{l}\text { ROCHA, Camil- } \\
\text { la R. Netto da } \\
\text { Costa }\end{array}$ & 2017 & ESPM \\
\hline $\mathrm{ME}$ & $\begin{array}{l}\text { Comunicação, educação e consu- } \\
\text { mo: a telenovela Lado a Lado e a } \\
\text { questão do negro no Brasil }\end{array}$ & $\begin{array}{l}\text { BARRETO, Ro- } \\
\text { sana Grangeiro }\end{array}$ & 2017 & ESPM \\
\hline $\mathrm{ME}$ & $\begin{array}{l}\text { O conceito de família na telenove- } \\
\text { la: um estudo sobre sua recepção }\end{array}$ & $\begin{array}{l}\text { ROCHA, Camil- } \\
\text { la R. Netto da } \\
\text { Costa }\end{array}$ & 2017 & ESPM \\
\hline
\end{tabular}

Fonte: Autor

Não é o caso aqui de quantificar (estudo bibliométrico) o número de vezes que determinados conceitos aparecem na obra selecionada para análise, também não é o caso de serem quantificadas as referências e citações de autores incorporados ao material selecionado. Podemos apontar, com certeza, por nossa experiência como leitora da obra de Baccega e pelo manuseio do material em análise, que autores bastante referenciados e que nortearam sua produção são aqueles vinculados aos estudos da linguagem, tais como Ferdinand Saussure, Roland Barthes, 
Michel Pêcheux, Adam Schaff, Umberto Eco, Eugenio Coseriu, Henri Lefebvre, Ferruccio Rossi-Landi, Mikhail Bakhtin, Dominique Maingueneau, Eni Orlandi, Augusto Ponzio, Louis Hjelmslev; e à História, à Cultura e à Comunicação, podemos referenciar: Fernand Braudel, Agnes Heller, Walter Benjamin, Michel de Certeau, Jesús Martín-Barbero, Paulo Freire, Klaus Jensen, Edgard Morin, Terry Eagleton, Fredric Jameson, entre outros; além dos clássicos Karl Marx, Friedrich Engels, Antonio Gramsci, Lucien Goldmann, Álvaro Vieira Pinto, Pierre Bourdieu, Octavio Ianni, Florestan Fernandes. Autores e conceitos referidos e formulados em uma ampla trajetória cujos fundamentos estão traçados em duas obras fundamentais da autora, construídas no percurso do doutorado e da livre-docência na USP e que resultaram em duas sínteses publicadas nos livros Palavra e discurso. História e literatura (1995); e Comunicação e Linguagem: discursos e ciência (1998).

Estão nessas duas obras os eixos teóricos mobilizados para o desenvolvimento conceitual dos anos seguintes, que estarão centrados na inter-relação de comunicação e educação; nos estudos de ficção televisiva/telenovela, lastreados pela concepção de campo da comunicação como espaço de interdependência de produção e recepção de discursos. Os contextos culturais e históricos que marcam os fatos econômicos e sociais aparecem por meio da circulação dos discursos, ou seja, os significados se constroem no contexto em que se dá a comunicação.

Nesse quadro aparece como natural a abordagem que Baccega faz dos estudos de recepção. Para ela, como dissemos, produção/recepção fazem parte de um só processo cujo fator comunicacional se dá na circulação e reelaboração dos discursos a partir da experiência e da realidade cotidiana de cada sujeito social. A questão do sujeito social é o eixo nevrálgico para compreensão do seu pensamento acerca do campo da comunicação e especificamente dos estudos de recepção. No conjunto da obra que constitui o corpus de nosso estudo, observamos como aspecto longitudinal de sua composição o aparecimento de temas e problemas em análise pela autora, atravessados pelo conceito de sujeito social, circulação dos discursos, ficção, história, telenovela, 
comunicação e educação, recepção e, por fim, consumo. Por exemplo: a palavra-chave consumo vai aparecer nas teses e dissertações que a autora orientou somente a partir de 2008, momento em que se consolidava o Programa de Mestrado em Comunicação e Práticas de Consumo da ESPM. Além da questão institucional que leva no nome o termo consumo, Baccega tratou de discutir e aprofundar em termos teóricos, em suas obras e orientações, o conceito de consumo. Sua perspectiva desvela um cenário novo de referências teóricas que vai se distanciar do emprego comum do termo no marketing, como discutiremos adiante. No caso do conceito de recepção ou dos estudos de recepção, Baccega dá uma contribuição fundamental, quando em 1994, no texto de apresentação da primeira edição da revista Comunicação ๒ Educação, afirma:

(...) a comunicação só acontece no encontro desses dois lados: "emissor" e "receptor". Os programas só acontecem quando nós os vemos e ouvimos; os jornais e revistas, quando os lemos.

Se é certo que a comunicação só se efetiva quando a "mensagem", aquilo que é dito, foi apropriado por quem recebe, por nós, então torna-se fundamental conhecer como funcionam os meios, para que tenhamos condições de conhecer melhor o mundo, buscando desvendar os mecanismos usados na sua edição (BACCEGA, 1994, p. 8).

Ao assim se referir à comunicação como processo que se dá entre emissão/produção/recepção, qualificando o sujeito como editor de um discurso já editado pelos meios de comunicação, sobreleva a importância das relações sociais e institucionais, como as da escola. É importante destacar que a Escola de Comunicações e Artes, da USP, recebeu a visita de Jesús Martín-Barbero, em 1993, em série de eventos organizados pelo prof. Mauro Wilton de Sousa. ${ }^{4}$ A partir desse contato, Baccega manteve estreita relação com a obra de Martín-Barbero, adensando suas reflexões às problemáticas teóricas que o autor ressaltou em De los médios a las mediaciones (1987) e em inúmeros outros artigos. Vale destacar a

4 É clássica a obra Sujeito, o lado oculto do receptor, publicada em 1995, com organização de Mauro Wilton de Sousa. 
entrevista que Baccega (1999) realizou com Martín-Barbero, na qual, além da trajetória de vida pessoal e acadêmica, o intelectual discorre sobre a comunicação, o trabalho e os desafios da contemporaneidade. A lucidez de ambos, Martín-Barbero e Baccega, choca pela capacidade de enunciarem temas tão atuais:

[Jesús Martín-Barbero]: Penso que a questão vai por este lado, é um desafio para pensar. Sinceramente, sou dos que crêem que a Antropologia é a chave, porque os desafios apresentados pela tecnicidade não são desafios puramente instrumentais, de aparelhos. Depois de tudo o que dissemos sobre mudanças de sensibilidade, de percepção do tempo, do espaço, vemos que por aí passa uma transformação que não cabe nas categorias com que cada ciência social está trabalhando (PAULINO; BACCEGA, 1999, p. 71).

A fala de Martín-Barbero destaca a relevância das temáticas comunicacionais, provocando um pensamento interdisciplinar, dando atenção especial à relação tempo/espaço. Dessa forma, vemos que a obra de Baccega (2011) está também lastreada nas preocupações teóricas e epistemológicas da contemporaneidade e compromissada com a "construção de uma nova variável Histórica”. No próximo eixo de discussão, trataremos da concepção de Baccega sobre discurso, linguagem verbal e sujeito social, bases fundamentais para a compreensão do processo de comunicação, ou seja, dos estudos de recepção.

\section{O sujeito social: os eus da comunicação na produção de sentidos}

Formada em Letras pela Faculdade de Filosofia, Letras e Ciências Humanas da USP, com uma trajetória profissional dedicada ao ensino, Baccega chega à Escola de Comunicações e Artes munida do conhecimento teórico-prático no campo da linguagem verbal e da análise do discurso para atuar como pesquisadora, professora e cidadã. A autora tem contato com obras primordiais que tratam a linguagem verbal no âmbito do discurso. Alguns autores foram importantes para esse 
desenvolvimento. Adam Schaff, com a obra Linguagem e conhecimento, traduzida para o português e publicada em 1974. Como afirma Baccega (1995a, p. 95), o autor trata da linguagem "a partir da práxis, numa postura dialética”. Essas também são duas palavras-chave no pensamento de Baccega: práxis e dialética. Outro autor importante na formação de sua concepção é Henri Lefebvre, com a obra A linguagem e a sociedade, em português de Portugal, publicada em 1966. A essas obras, somam-se os autores originários da linguística, base de sua formação, da análise de discurso, Michel Pêcheux, e dos estudos da linguagem, Mikhail Bakhtin e Valentin Volóchinov. ${ }^{5}$ Os autores nomeados abordam a linguagem como produção do coletivo que é a sociedade, produção social e cultural que enforma o movimento das relações sociais e das novas gerações. Então a linguagem verbal é criação humana coletiva, social, civilizacional, cultural, sempre renovada por meio da dinâmica de sua construção ao longo do tempo histórico. O resultado do discurso é produto da práxis social; do movimento dialético, que compreende as contradições da vida objetivamente vivida. Assim, para Baccega a língua é uma produção coletiva, marcada pelos valores da sociedade em um tempo histórico, mas que reserva em camadas de sentidos a trajetória dos falantes. Sempre a ser contextualizado, o discurso revela as mais sensíveis mudanças sociais, acepção de Volóchinov com a qual Baccega já trabalhava na escrita de seu doutorado e livre-docência. O trecho abaixo do livro Comunicação e linguagem. Discurso e ciência (1998a) é um bom termômetro para indicar o pensamento de Baccega sobre a linguagem.

As relações de classe influenciam as práticas linguísticas. Nesse sentido, podemos dizer que a história está na língua: as realizações linguísticas (discursivas) trazem inscritos os valores atribuídos, as diferenças de interesses, as propostas de direções diversas para o mesmo processo histórico. Assim é que signos verbais - palavras - terão sentidos diferentes, dependendo das formações ideológicas em que se encontram. Outras vezes, signos diferentes passam a ter o mesmo sentido, de acordo com tal dependência (BACCEGA, 1998a, p. 20).

5 Valentin Volóchinov autor de Marxismo e Filosofia da Linguagem, membro do Círculo de Bakhtin. 
Reverberando tal linha de pensamento para o conceito de sujeito, tão maltratado por inúmeras concepções do idealismo filosófico, Baccega (1995a, p. 23) afirma: "quando falamos em subjetividade, não podemos perder de vista que ela é formada a partir da materialidade constituída pela manifestação dos vários discursos, instituindo um eu plural”. Essa ideia "eus", vozes que estão presentes em nosso próprio discurso, como camadas do vivido e do reelaborado de outros discursos, dá a essa voz o que a autora define: "é no eu plural que se articulam estruturas e processos". Ou seja, opera aí a relação dialética, contraditória que se estabelece entre os meios de produção e as forças produtivas, tendo em vista que os sujeitos que trabalham compõem as forças produtivas. Dessa maneira, Baccega discute uma questão fundamental:

É nesse eu plural que se articulam estruturas e processos. Nele estão presentes tanto os resultados do percurso histórico daquele grupo e/ou classe social, que condicionam as ações, quanto os processos das ações e a efetivação dos comportamentos dos indivíduos/sujeitos (BACCEGA, 1995a, p. 23).

Desta feita, o receptor nunca pode ser tratado na obra de Baccega como polo oposto da comunicação que recebe a mensagem e responde tal qual um autômato. Para ela, a comunicação é processo de relações entre enunciadores e enunciatários, no qual a produção do discurso (mensagem) está conformada pelas significações dadas pela interdiscursividade, ou seja, pelo diálogo que todo discurso pressupõe. Diálogo constituído, inclusive, pelo mínimo dialógico (BAKHTIN, 2002) do discurso interior. Para coroar esse pensamento, Baccega (1995, p. 27) afirma: "Há que se perceber o ‘deslocamento’ dessas significações: a produção do sentido está na sociedade, está na história”.

Assim, a centralidade sobre a concepção de linguagem orienta o pensamento de Baccega para entender o campo da comunicação - processo de relações entre emissor/receptor e história - e os conceitos de mediação, recepção e consumo. Temas que abordaremos nas próximas linhas. 


\section{Mediações, recepção e consumo: conceitos a partir dos quais pensa a comunicação}

Na obra de Baccega tem total relevância sua compreensão sobre a linguagem verbal e a circulação dos discursos no processo comunicacional, este tido como um campo de inter-relações marcadas pela historicidade das lutas de classe. A linguagem verbal nessa acepção é a mediadora privilegiada entre o ser e o objeto, sempre em relação interdependente. Não há como exercer a comunicação e construir sociedade sem um sistema de signos a mediar nossa relação com o mundo da natureza e da cultura. Assim, quando se trata de estudar as mediações comunicativas da cultura, ou antes, as mediações da cultura nas práticas comunicacionais, para Baccega trata-se de observar sobretudo o sistema de signos, privilegiando a linguagem verbal. A linguagem nos constitui e joga ponte entre nós e os outros.

Para que haja comunicação, é preciso que os interlocutores tenham uma "memória" comum, participem de uma mesma cultura. Isso porque a comunicação se manifesta nos discursos e os discursos que circulam na sociedade se constituem a partir da intertextualidade (BACCEGA, 1998b, p. 8).

Essa compreensão remete aos meios de comunicação e à sua potencialidade na produção/circulação de discursos, tendo aí inserida a concepção do receptor, expressão de seu lugar na história, na luta para se constituir como sujeito/cidadão. Essa relação de reciprocidade constitutiva pode ser observada em um trecho de seu artigo na revista Comunicação ๒ Educação.

Precisamos ter claro que a significação do "conteúdo" dos meios só se completa no momento em que alguém ouve, lê ou vê. Nesse momento, o receptor agrega ao significado que recebe o significado que sua cultura lhe possibilita depreender. Aí está um dos níveis das mediações. A identidade do cidadão, do ser brasileiro, está relacionada à "imagem” que os meios de comunicação divulgam. Como é o país onde vivemos, quais os traços, os comportamentos de nosso povo que nos unem uns aos outros? Aqui, são os meios de comunicação que se constituem, eles próprios, 
como mediações privilegiadas. Este é um outro nível das mediações. São elas que colaboram para a instituição de nossa identidade como indivíduo/sujeito e como cidadão (BACCEGA, 1995b, p. 8).

Ao enfatizarmos esse enunciado de Baccega, o que estamos reafirmando é que as mediações, para além das especificidades de identidade, mobilidade, temporalidade, cognicidade, espacialidade, tecnicidade, fluxos e ritualidade, apresentam-se como elementos que estão presentes no discurso, e estão ancorados na história das relações sociais; ao mesmo tempo, constituem-se como espaços simbólicos que encerram relações dialógicas e dialéticas. Conquanto esses diferentes planos de mediações possam ser operados em pesquisas, não se pode operá-los separadamente de uma compreensão de totalidade do processo de constituição dos sentidos e, desse ponto de vista, de clareza sobre o papel dos meios de comunicação na constituição dos discursos que circulam na sociedade.

Ainda sobre as mediações, Baccega em artigo que recuperamos via Google, com template da Compós, mas fora dos Anais dos Encontros anuais, e também não publicado na E-Compós, afirma:

(...) o processo de conhecimento, que não se confunde com o objeto em estudo, com o produto em exposição, deverá sempre levar em consideração a existência das mediações, procurando torná-las claras, quer seja nas percepções parciais da realidade (o trecho de rua que vejo a partir do ponto onde me coloco para "ver"), quer seja na perspectiva da totalidade, a cuja configuração complexa a mediação garante o movimento, a dinâmica, as inter-relações (BACCEGA, s/d on-line).

Baccega nos chama a atenção para a condição de sujeitos históricos que "fazem história mesmo sem saber que a fazem"; no entanto, nosso esforço, e o dos estudos de recepção, é para caminhar em direção a que os sujeitos façam história a partir da consciência de suas tomadas de posição, no movimento do particular para o geral, assumindo o que Bakhtin (2010) chamou de responsividade (como resposta e responsabilidade).

Longe de propor uma teoria e uma metodologia para os estudos de recepção, o que Baccega faz é demonstrar e trabalhar os conceitos que 
subjazem os processos de recepção, afastando-se de proposições funcionalistas que tratam o receptor como público-alvo, massa amorfa, captada a partir de um conjunto de dados, redesenhada e abordada com mensagens "direcionadas". No mesmo artigo (s/d on-line), Baccega faz um esforço para tratar da metodologia dos estudos de recepção:

captar dialeticamente o movimento do 'ser social', torna-se indispensável "a busca das mediações enquanto condutos onde as categorias concretas se movimentam dando sentido ao processo histórico". (....) Essa busca das mediações significa, no plano metodológico, a captura das articulações e passagens vivas que se processaram entre as instâncias envolvidas na trama histórica (BACCEGA, s/d on-line).

Baccega, na tradição de Martín-Barbero, entende o receptor na dialética da luta do sujeito para ser dono de sua enunciação e compreender a inter-relação profunda entre os discursos circulantes, os ditos e os não ditos, os silenciados, pois o silêncio também significa (ORLANDI, 2007). Entender os processos de recepção é entrar na arena de lutas que se dá pela linguagem. Exemplo maior estamos vivendo agora, com o dicionário neoliberal (DARDOT; LAVAL, 2016) adotado em todos as instâncias sociais: o/a empreendedor/a, as competências e habilidades, o livre mercado, a competitividade. Esses elementos discursivos, como mantra ideológico, estão presentes desde os reality shows até a sala de aula do ensino elementar (empreendedorismo na escola). ${ }^{6}$ Estão presentes, sobretudo, no discurso do sistema financeiro, como muitos de homens de Estado de forma consciente e posicionada; ou até no discurso do motorista de Uber que se vê como empreendedor, na ilusão de sua labuta cotidiana pela sobrevivência (HELLER, 1970), sem a perspectiva da totalidade.

Baccega entende o receptor no movimento conflituoso por expressão e tomada de consciência de lugar histórico que todos temos, relega, por outro lado, ao público-alvo, o papel de consumidor. Até início dos anos 2000, Baccega discutiu o receptor na dimensão do sujeito social e o

6 Ver o site Empreendedorismo na escola - Conectas exponenciais. Disponível em: https:// escolasexponenciais.com.br/inovacao-e-gestao/empreendedorismo-na-escola-por-que-investir/. 
consumidor como aquele indivíduo disputado pelo mercado da publicidade. É interessante ver sua manifestação sobre o tema:

Nesse caminho podemos distinguir os estudos de recepção dos estudos de consumo. O simples fato de uma campanha de chocolate ter efetivamente possibilitado a venda de um número maior de chocolates não indica que houve recepção como a estamos entendendo. Indica apenas que houve apropriação, transitória, de alguma coisa. E estaríamos aí no campo do consumo. Logo, não é pelo fato de uma campanha publicitária ter obtido sucesso de vendas que poderemos afirmar que o sujeito receptor ressignifiçou comportamentos culturais, incorporando-os à sua prática. Recepção é um processo lento e contínuo e não se mede apenas pela quantidade (BACCEGA, 1998b, p. 10).

Essa posição será friccionada à dinâmica da vida, quando Baccega recebe o desafio de formular a proposta (com um coletivo de outros acadêmicos) para o mestrado na ESPM. A marca de uma escola tradicional no âmbito da publicidade e do marketing se fará presente no escopo de um programa de estudos acadêmicos, no entanto, o compromisso com a ciência e com a história estão presentes na trajetória de Baccega, o que a fará estudar esse novo desafio no nível profissional e de conhecimento científico. São anos de depuração em que a autora vai aprofundar sua reflexão sobre o sujeito histórico e sobre o funcionamento do capitalismo. Aquilo que marcou a obra da autora em termos de movimento reflexivo dialético e pluridisciplinar será retomado para sair do que ela denominou como 'estereotipia' no uso dos conceitos, assim formulando a abertura de um de seus artigos "O conceito de consumo é um dos territórios em que, bem mais que outros, a estereotipia ocupa lugar de destaque" (BACCEGA, 2009, p. 108). Ou seja, ela reconsiderou o que afirmou em 1998, em artigo acima citado para a revista Comunicação \& Educação. Mas, no artigo de 2009, Baccega vai adiante: retoma García Canclini, em Consumidores e cidadãos, em sua frase paradigmática: "o consumo serve para pensar", e exemplifica com citações da fala de Sinhá Vitória, personagem de Vidas Secas, por meio da qual Graciliano Ramos denuncia: 
Seu Tomás tinha uma cama de verdade, feita pelo carpinteiro, um estrado de sucupira alisado a enxó, com as juntas abertas a formão, tudo embutido direito, e um couro cru em cima, bem esticado e bem pregado. Ali podia um cristão estirar os ossos (RAMOS, 1980, p. 46).

Os desafios que a fazem refletir sobre uma revisão da separação que cunhou entre receptor e consumidor apontam novos autores para serem estudados e incorporados à sua obra. García Canclini, já conhecido; Jameson, Bauman, Quesada e Augé serão lidos e/ou relidos na chave de revisão do conceito anterior de consumo. Esse esforço a faz dialogar com Celso Frederico, velho amigo intelectual dos tempos de USP, para retomar Marx e a Introdução à Crítica da Economia Política, que abre o primeiro tomo dos Grundrisse. Esse momento parece ser um reencontro com os fios dos discursos anteriores, um repensar o conceito para, novamente, perceber que também o consumo, assim como o receptor, precisa ser lido na tecla da totalidade histórica, aquela do desenvolvimento das forças produtivas e da luta de classes. Desse modo, Baccega traz para o âmbito da pós-graduação em Comunicação e práticas de consumo a assombração do velho barbudo. Mas é exatamente aí que o estudo do consumo toma fôlego e distinção acadêmica.

Em artigo para a revista Animus, da UFSM, em 2009, Baccega escreve:

Consumo e produção são duas faces da mesma moeda. Ou seja: "a produção é imediatamente consumo; consumo é, imediatamente, produção. Cada qual é imediatamente seu contrário" (MARX, 1992, p. 8). Ocorre que a produção constitui-se na grande mediadora do consumo, pois ela cria os materiais que serão utilizados na confecção do objeto. Por outro lado, o consumo é também o grande mediador da produção, pois ele cria "para os produtos o sujeito, para o qual são produtos. Sem produção não há consumo, mas sem consumo tampouco há produção” (MARX, 1992, p. 8apud BACCEGA, 2009, p. 113).

Esse excerto de Marx nos rascunhos (Grundrisse) de O Capital será retomado inúmeras vezes para fazer pensar o funcionamento da vida social entre produção e consumo. Ressalte-se que Marx está fazendo 
a crítica a certas posições de economistas - da Economia Política, que perderam a dimensão das relações dialéticas e contraditórias do sistema de produção do capital, aquelas que se manifestam entre a produção e o consumo, e dizem respeito tanto às bases materiais da vida - na acepção da economia, do trabalho, das matérias-primas, da terra, do desenvolvimento fabril - quanto às bases da vida que dizem respeito à organização da sociedade, da cultura, da política, da arte. A autora assim se manifesta:

Duas faces da mesma moeda, tal qual o signo, o produto só recebe seu acabamento final no consumo, ou seja, a concretização, a significação do produto está no consumo, assim como a concretização do signo verbal a palavra - está na dinâmica da vida social (BACCEGA, 2009, p. 114).

Ou seja, o movimento que Baccega faz é o de ressignificação do que seja produto (objeto, comida, carro, vestido, mercadoria, cinema, programa de TV etc.) para tratar produto como signo. Sem dúvida, signo é produção material da vida em sociedade, somente no grupo social o ser humano desenvolve-se para a comunicação e, portanto, sua condição de produtor de signos. Os signos no capitalismo passaram a uma mercadoria essencial. Desde Aristóteles, sabemos do poder persuasivo do discurso. Mas não é de persuasão apenas que trata Baccega, ela retoma os conceitos marxistas, também em Volóchinov, com a ideia do signo ideológico, para voltar a Rossi Landi, quando este trata da "A linguagem como trabalho e como mercado". Certamente, ao voltar aos Grundrisse, Baccega coroou sua compreensão do conceito de consumo no contexto contemporâneo, ou seja, da trama social em que disputam espaço o cidadão em detrimento do consumidor. Mas o consumidor na boca grande dos enunciadores hegemônicos é similar ao receptor massa amorfa ou ao desvario do consumidor/receptor todo-poderoso. A marca que Baccega traz e a ela se aferra é a da compreensão dialética da luta de classes que sobretudo se manifesta na arena dos signos e, portanto, nos estudos da comunicação. 
Vale destacar mais um trecho da obra referida de Marx e que é seguidamente citado por Baccega:

Cada um não é apenas imediatamente o outro: cada um, ao realizar-se, cria o outro. O produto não se torna efetivo senão no consumo; por exemplo, um vestido converte-se efetivamente em vestido quando é usado; uma casa desabitada não é, de fato, uma casa efetiva; por isso mesmo o produto, diversamente do simples objeto natural, não se confirma como produto, não se torna produto, senão no consumo. Ao dissolver o produto, o consumo lhe dá seu retoque final, pois o produto não é apenas a produção enquanto atividade coisificada, mas [também] enquanto objeto para o sujeito em atividade (MARX, 1992, p. 8).

Essa compreensão proporciona-lhe um salto de qualidade na reflexão sobre as relações entre comunicação/consumo/recepção. Vai aplicá-las também aos âmbitos da escola e da ficção televisiva, que discutiremos no próximo tópico.

\section{Produção-Recepção-Consumo - nos estudos de telenovela e comunicação/educação}

Baccega coordenou o projeto de pesquisa ${ }^{7}$ com apoio da Fapesp para estudar telenovela, esse foi o feito que uniu um conjunto de intelectuais da ECA-USP para estudar o formato de ficção televisiva mais popular do mundo. Anteriormente, o melodrama brasileiro era estudado na ECA, mas o grupo liderado por Baccega tomou o tema com tal abrangência teórica e metodológica que de lá, idos da década de 1990 até hoje, não parou de ser estudado, inclusive por ela. Mais especificamente a recepção da telenovela foi discutida em artigos, em projetos de pesquisa e em teses e dissertações que orientou, bem como em sua liderança na vice-coordenação do Obitel (Observatório Ibero-americano de Ficção Televisiva). No âmbito desse observatório, Baccega orientou inúmeras

7 Trata-se do projeto: O campo da comunicação: os valores dos receptores de telenovela (1995); parte do projeto coletivo: Ficção e Realidade: a telenovela no Brasil, o Brasil na telenovela. Fizeram parte do grupo de pesquisadores as professoras da ECA-USP: Maria Lourdes Motter; Mary Enice R. Mendonça, Maria Immacolata V. Lopes, Solange Couceiro Lima, Renata Pallottini e Maria Cristina C. Costa. 
pesquisas e publicou livros e artigos. Vale destacar a compreensão dela sobre a questão da transmidialidade nos estudos de recepção discutindo ficção televisiva em artigo sobre o estudo de recepção da novela Morde E Assopra.

(...) relação com o consumo, por sua vez, se torna mais pertinente quando Scolari sugere que a teorização das hipermediações enxergue o consumidor além do seu papel de ressignificador de conteúdos, indo para o "território onde o consumo se volte à produção - lugar em que a criação intertextual se manifesta". Da mesma forma, Martín-Barbero destaca a importância de se olhar para as mediações tecnicidade e ritualidade, que podem ser analisadas no contexto transmidiático (BACCEGA; ANTONACCI, 2013, p. 90).

Vê-se a preocupação das autoras para tratar o consumidor como parte do circuito da comunicação e, portanto, também como produtor de discursos. Essa preocupação pode ser conferida em artigo no qual ela (BACCEGA et al., 2015) estuda a recepção da música popular, o rap na periferia de São Paulo. Afirmam as autoras:

[o estudo] procurou compreender como a cultura midiática e de consumo figuram nas narrativas (letras das músicas) de um grupo de rap da periferia de São Paulo e como são recebidas entre jovens da capital paulista, procurando entender os sentidos de consumo e de cidadania que aí se constituem (BACCEGA et al., 2015 p. 47).

Estão entrelaçadas recepção/consumo/discurso, em uma aproximação com a educação/cidadania. O tema da inter-relação comunicação e educação será discutido a partir da necessidade de estudá-lo frente à sua ampla presença em nossa sociedade e, em especial, na escola. Afinal, como Baccega enfatizava: mesmo que os meios não estejam na sala de aula presencialmente, eles o estão por meio dos estudantes (receptores/ consumidores).

Voltando à discussão da pesquisa relatada no artigo, as autoras afirmam essa aproximação ao adotar os seguintes eixos para o estudo: 
(...) pesquisa buscou (a) articular, teoricamente, os vértices da Comunicação, da Educação, do Consumo e da Cidadania; (b) compreender o lugar de fala do grupo em questão; (c) analisar as produções desse grupo de rap da periferia de São Paulo e (d) realizar um estudo de recepção dessa vertente musical entre jovens paulistanos (BACCEGA et al., 2015 p. 47).

A pesquisa a que se reporta o artigo trata, conforme Baccega já vinha fazendo, os conceitos de recepção/consumo/educação. Esse movimento final em sua produção teórica ela o fez por meio de projetos de pesquisa de seus alunos, do Obitel e do Programa de Pós-graduação em Comunicação e Práticas de Consumo. A orientação é mergulhar em pesquisas empíricas para buscar elementos da vida cotidiana que pudessem iluminar suas reflexões sobre esse processo de recepção e consumo. Ainda no mesmo artigo, as autoras afirmam:

Por meio dos estudos de recepção, buscamos entender como são construídas as interações que ocorrem no bojo da sociedade e como se desenvolve esse processo de negociação de sentidos. (...)

Enfim, buscamos compreender as percepções dos estudantes acerca de questões sociais, da periferia e do consumo; e entender como recebem as mensagens das músicas do rap a partir de suas práticas sociais (idem, p. 48).

Baccega e as autoras mostram que as negociações de sentidos são o objeto que se busca desvelar. Como no processo de recepção, os estudantes percebem as questões sociais incluídas aí as do consumo na periferia. Ou seja, Baccega aprofunda a perspectiva teórica de que os discursos revelam os sentidos circulantes das e nas práticas sociais de jovens no processo de recepção e do consumo do rap na periferia paulistana. A articulação de recepção, consumo e educação se dá pelo eixo da política, ou seja, pela cidadania. Ou poderíamos também afirmar que a articulação entre recepção, consumo e cidadania se dá pela educação. Aí Baccega deixa completamente clara a coerência de sua perspectiva teórica: a educação como ação política do sujeito histórico. O sujeito crítico forjado no ambiente da educação dialógica freiriana. 
É um reencontro, na verdade uma rearticulação com a comunicação/ educação. Tanto essa concepção marcou sua trajetória que, em 2019, foi homenageada pela ESPM e o Programa de Pós-graduação em Comunicação e Práticas de Consumo com a Cátedra Comunicação, Educação e Consumo Maria Aparecida Baccega.

\section{A título de uma síntese, caminho para outras discussões}

Baccega cunhou sua trajetória a partir dos estudos da linguagem verbal. Ela compreendeu o campo da comunicação como processo de produção e recepção, dado que as mediações da linguagem são mediações fundamentais para os seres humanos. O signo linguístico é uma arena de lutas por posições as quais revelam as formações ideológicas em que os discursos sociais vão disputando os sentidos hegemônicos. Estudar a recepção/consumo sem compreender a dimensão do sujeito social e como ele se forma nessa arena discursiva é simplificar e tentar moldar o que é complexo por meio de cristalizações simplistas.

Compreender a recepção e o consumo como aspectos do processo de produção de sentidos e de visões de mundo, de valores e de posições de classe foi a proposição deixada pelas obras de Maria Aparecida Baccega. O conjunto de textos de sua autoria ou co-autoria mostra-se substancioso e um desafio para os estudiosos da comunicação, sobretudo da vertente dos estudos de discurso, recepção e educação. Os discursos que Baccega enunciou no processo de produção de um conhecimento sobre a comunicação estão aí como mais um elo da interdiscursividade sempre inacabada, porque a voz do outro sempre pode trazer mais um desafio a se enfrentar.

\section{Referências}

ASSIS, Francisco de. Estrada interdisciplinares no percurso de Maria Aparecida Baccega. Notas para uma biografia intelectual. [s.d.]. Disponível em: https://www.yumpu.com/pt/ document/read/12767721/estradas-interdisciplinares-no-percurso-de-maria-aparecida-unesp. Acesso em: 17 fev.2020. 
BACCEGA, M. A. Comunicação/educação a construção de nova variável histórica. In: CITELLI, Adilson Odair; COSTA, Maria Cristina Castilho (Org.) Educomunicação: construindo uma nova área de conhecimento. São Paulo: Paulinas, 201 1, v. 1, p. 31-42.

. Inter-relações comunicação e consumo na trama cultural: o papel do sujeito ativo. Animus (Santa Maria Online), v. 15, p. 1-15, 2009. 7-14, 1994.

. Do mundo editado à construção do mundo. Comunicação $๒$ Educação, (1),

Palavra e discurso: história e literatura. São Paulo: Ática, 1995a.

. Comunicação e Mediações. Comunicação \& Educação (USP), Editora Moderna, São Paulo, v. 1, n. 4, p. 7-12, 1995b.

. Comunicação e Linguagem: discursos e ciência. São Paulo: Editora Moderna, 1998a.

Recepção: nova perspectiva nos estudos de Comunicação. Comunicação ๒ Educação, São Paulo, v. VI, n. 12, p. 7-16, 1998b.

. O campo da comunicação/educação e as práticas de recepção: o papel das mediações. [s.e.] s.d.]. Disponível em: http://www.compos.org.br/data/biblioteca_1283.pdf. BAKHTIN, M. (V. Volóchinov) Marxismo e filosofia da linguagem. São Paulo: Hucitec, 1988.

BAKHTIN, Mikhail. Para uma filosofia do ato responsável. São Carlos: Pedro \& João, 2010.

BUDAG, F.B.; MARCELINO, R.; ABRÃO, M. P.; BACCEGA, M.A. Consumo e Cidadania: em perspectiva a recepção do rap da periferia paulistana. Comunicação 6 Educação (USP), v. 20, p. 47-55, 2015.

GARCÍA CANCLINI, Néstor. Consumidores e cidadãos: conflitos multiculturais da globalização. Rio de Janeiro: Editora UFRJ, 1995.

HELLER, Agnes. O cotidiano e a história. São Paulo: Paz e Terra, 1989.

MARTIN-BARBERO, Jesús. De los medios a las mediaciones. Comunicación, cultura y hegemonía. Barcelona/México: Gustavo Gilli, 1987.

MARX, Karl. Para a crítica da economia política. São Paulo: Abril Cultural, 1992.

ORLANDI, E. P. As formas do silêncio. No movimento dos sentidos. Campinas: Editora Unicamp, 2007.

PAULINO, R. A.; BACCEGA, M. A. Sujeito, comunicação e cultura (Entrevista com Jesús Martín-Barbero). Comunicação ๒ Educação, (15), 1999, 62-80.

RAMOS, Graciliano. Vidas secas. São Paulo: Record, 1980.

VOLOCHINOV, V. Marxismo e filosofia da linguagem. São Paulo: Editora 34, 2017. 
426 CONTRIBUiÇÕES DE MARIA APARECIDA BACCEGA

\section{Sobre a autora}

Roseli Figaro - Professora Livre-docente da Universidade de São Paulo. Possui estágio de pesquisa pós-doutoral no CIESPAL e pós-doutorado pela Universidade Aix-Marseille, França, doutorado e mestrado em Ciências da Comunicação pela Universidade de São Paulo e graduação em Jornalismo pela Faculdade de Comunicação Social Casper Líbero.

Data de submissão: 16/06/2020

Data de aceite: 20/08/2020 